\title{
連載
}

\section{ナショナル・トラスト・ ワーキング・ホリディー(4)}

板 倉豊

(京都精華大学)

\section{§ 4 キャンプ地・エクスムーアへ}

Ł1999．10．23（土）ロンドン，小雨

ロンドンからキャンプ地へ移動

3 日目。朝食後，少し早いが列車のことが気に なって早めにチェックアウトする。旅行用トラン クをゴロゴロころがしてパディントン駅へ，週末 とあって駅は物凄い人。キップを売る空口もイン フォメーションの密口も長蛇の列。ヨーロッパの 駅は皆そうだが改札口はない。プラット・ホーム の手前の広場に今から出る列車の案内がテレビ画 面に表示される．駅に着くのが少し早かったので 私が乗る予定の列車の表示はまだない。駅の様子 を少し観察していると, 自分達が乗る列車の表示 が出てから，20～30分前になってやっとどこのプ ラットホームなのかの番号が表示される。すると 人々はどーっとその番号のホームに移動する。そ れまでは何番ホームかが決まっていないのだ。つ いでに座席予約システムについて言及すると，予 約は料金はかからない（日本なら400円程度割高に なる)，予約しなくても当日あいている席に早くす わったもの勝ちである。予約席には仕切りの肩の 部分に名前を書いたカードが付箋のように付けて ある。カードのない席は自由席だからだれが座っ

図ー1 イギリス

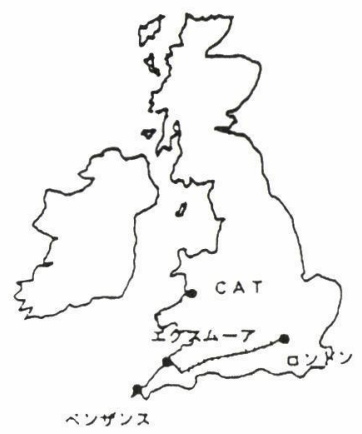

てもよいことになる，日本のようにこの車両は指 定席で後乃 3 両が自由席というわけでなく, 同じ 車両でもモザイク状に指定席（予約席）が存在す ることになる。ある時などほとんどカードが貼っ てあって自由席がほんのちょっと，というときが あったが，今回の旅行中，私は悪運が強く何時で もなんとか座ることができた。案内掲示板を見て いると，時々キャンセル（その理由も運転手の手 配ができないから！）なんて書いてあるので心配 になってきて，インフォメーションの窓口に並ぶ ことにした．やっと私の番が回ってきて，行き先 と事前に日本ナショナル・トラスト協会の藤田さ んに調べていただいた時間の列車のメモを係の人 に見せると，あにはからんや，「それは，予定変更 になったから，この時間の列車に乗るように」と メモをくれた。これがこの人の仕事で，連絡の駅 や乗換えの時刻まで書いたメモを渡すのである. これを持ってキップ売り場にまた並んでやっとキ ップが買える仕組みなのである。幸い私の場合は ブリット・パスを既に日本で購入済みだったので 後者の時間のロスは防げた。掲示板にそのメモど おりの列車の表示が出るまで辛抱強くまっていた が，一向にそれらしき列車の表示がでない．横に 立っていた女子学生らしい女の子に、私はバー ン・ステープルに行きたいのだけれど一向に列車 の表示がでないのだけれどもと相談してみた，彼 女は私のメモもしげしげと見ながら表示板に目を やって, 曰く「インフォメーションの人は時々間 違えるのよ，とても変更が多いから」

メモの列車の発車時刻（午前10時45分）のやっ と10分前に突然列車の案内と発車ホーム番号の表 示が出た，その辺にいた人々が一斉に反応して動 きだした，遅れてなるものかと，トランクを押し ながら目指すホームに向かった。1等車両が大体 


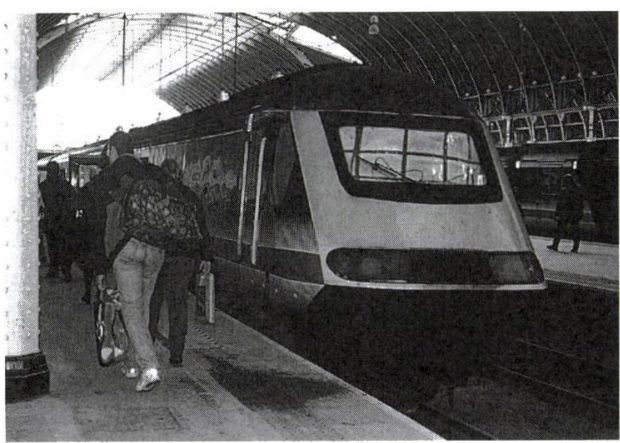

写真ー 6 英国の民営化された鉄道

うしろにある，これは先頭がディーゼル機関車な ので煙と音から遠ざけるためで，合理的な差別で ある，空から䙼きこみながら，なるべく予約カー ドの少ない車両をみんな探している。私もま权を して, カードの少ない車両を探してやっと乗車で きた。ドアは自動ではなくて自分で開けないと開 かない，乗る時は外側に取っ手があるのでわかり やすいが，内側から降りる時は空をいったん降ろ して，手を外に延ばしてノブを回さないと開かな い.ほけーっと待っていたら列車は出発してしま

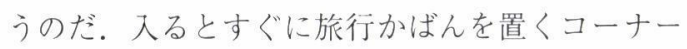
があって，大きなトランクはそこに置ける。その 反対側は車イスを固定できるスペースになっている.

イギリスでは 1994 年 4 月 1 日に国有であったブ リティッシュ・レイルウェイを日本のように分割 民営化してしまった，評判は前よりもっと悪くなっ て最低のサービスになってしまった。同じ駅に幾 つも会社の色の違った列車が止まっていて, 同じ 方向にグレート・ウエスタン・レイルウェイ会社 (緑色の車体) とバージン・レイルウェイ会社（赤 色の車体) の列車があったりして, 慣れない私は 混乱してしまった。とにかくグレート・ウエスタ ン・レイルウエイ会社のペンザス（イングランド の一番西の端）行き特急に乗り込むことができた。 列車は定刻を10分遅れて音もなく（日本のように 発車のアナウンスもべルもありません）発車した。 テーブルの上に鉄道地図を広げて車空の景色と駅 名を照合していった。1999年の8月にこの始発駅 パディントンをすぐ出た所で通勤列車と特急が正 面衝突（！）して20数名死者をだす大事故を起こ したところである。これだけレールの数が多く複 雑に入り組み, 違う会社がたくさん乗り入れてい れば混乱は起こるだろうと思ってしまった。 2 力
月もたっているので事故現場はどこかわからない ぐらい整頓されていた。 ストーン・ヘンジで有名 なソールズベリー駅付近を通過, 時間があれば訪 れたい土地であるけれど，今回はあきらめること にする，車内のビュッフェでインド・チキンカレ ーとオレンジジュースを買って昼食をとった〈5.5 ポンド1100円). 結構おいしかった.

2 時間たって乗換え駅のエクゼター・セント . デービッドにちゃんと定刻通り着いた。 12 時53分. ホームの案内掲示板を見て最終目的地バーンス テープル行きの列車の発車ホームの番号を必死で 捜す。乗換え時間は20分ほどあるけれども荷物は 多いし，違うホームに移動するには長い階段を上 下に移動しなけ札ばならないので，できるだけ早 くホーム番号を知りたかった，10分前になってや っとホーム番号の表示が出て, あわてて重たい卜 ランクを引きずって隣のホームに移動した。1 13 時 14 分発の列車がやっと 25 分にホームに入線してき た。たった 2 両連結のローカル線である, 1 時間 ほどローカル線に摇られて最終目的地のバーン・ ステープル駅に定刻どおり（!?）14時17分に着い た. 約束の時間より 2 時間も早く着いたので, 駅 の周りを散歩することにした。駅にはポテトチッ プスとコーラの自動販売機があるだけで駅員も 1 人しかいない. 駅の周りも今日は土曜日なので店 が皆閉まっている。雨も降り出し, 荷物を預かっ てくれと，ただ一人の女性駅員にお願いしたが, 私も今から買い物に行くので駅を 16 時まで閉鎖す るから駅構内から出ていってくれとのたまう. 居 合わせた年配のおばあちゃんが雨が降って寒いの で駅構内にこのまま居させてくれと不平をいった が,「アイムソーリー」と情け容赦なく駅構内をオ ン出されてしまった。しかたなく駅舎のわずかな 庇の部分で雨宿りした。

定刻になって1台のオンボロワゴン車が駅前を 通過した，多分あれだろうと目星を付けていた通 り, 車からナショナルトラストのオーク（カシ・ ドングリ) の葉っぱのマークを付けた緑色のツナ ギの作業服を着た初老の紳士が降りてきて私に近 付いて来た，握手をしょうと手を出しかけたら， 1 人手前で同じように雨宿りしていた女性に挨拶 をして握手をし始めた。 彼女も同じナショナルト ラストのワーキングホリディの参加者だったのだ. あとでわかったが, 彼が今回のキャンプのボラン 


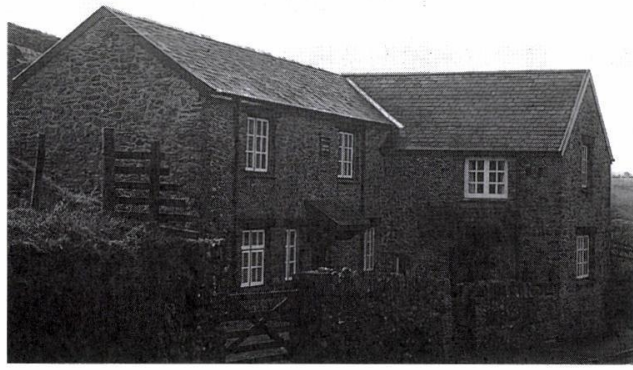

写真-8 カウンティスベイのベースキャンプの建物

\section{写真－ 7 愛犬のシッド}

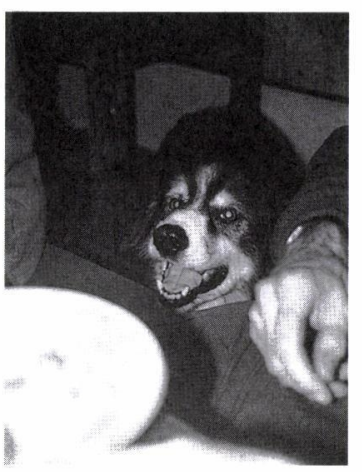

ティア・リーダーのクライブさんであった。また 並んで雨宿りしていた女性は看護婦さんのキャロ ルさんであった。少し待つと次の列車でニュー ジーランドからのバルさんという元気のいいお ばーちゃん（65歳）がやってきた。ベースキャン プのカウンティスベイは鉄道の終点駅バーンス テープルから車でまだ30分ほど海岸 (北)に向かっ た所だった、いけどもいけどもなだらかな丘陵地 带が続き，羊と牛が放牧されていた。途中，リン モスという海岸の観光地の村を通過してブリスト ル湾に出てきた。そそり立つ断崖（クリフ）から の景色はまさにアーサー王伝説にでてくるイング ランドの景色だ。この海岸をさらに西に進めばアー サー王誕生の地の一つとされるティンタジェルが すぐそばである。カウンティスベイのベースキャ ンプはこの岬の断崖の中腹にあった。

キャンプに着くとこのキャンプ地を預かるボー デン（責任者）のティムさんに迎えられた。本 にいる間に何度か手紙とメールをやりとりをした 人で，持ち物とかこのキャンプ地の特徴とかかな り情報をくれた，コらに帰国途中に立ち寄る CAT （自然エネルギーセンター）の情報も送ってくれた

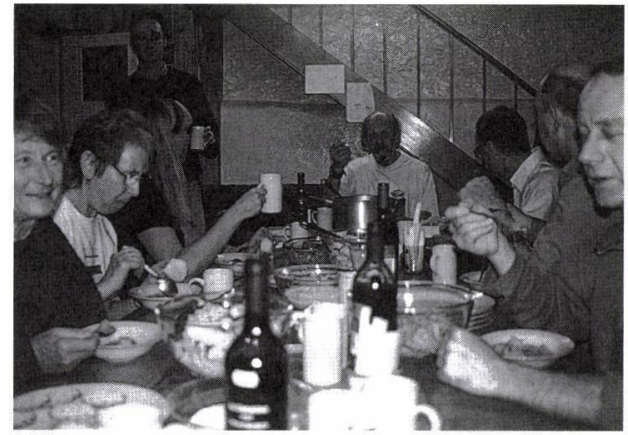

写真-9 夕食風景(毎食豪華イギリス田舎料理!? $)$

りした。親切な人だ。同時に彼の愛犬のシッドに も対面した，御年 14 歳で，人間で言えば 90 歳の老 犬である，滞在中はずっと我々の作業にくっつい て山にきて，我々を和ませてくれた。

遅れてくる 1 人の女性参加者を除いて全員そ ろって夕食となった。 ナショナルトラストのワー キング・ホリディーの参加者の構成は必ず男女 半々で, 今回も女性 5 名, 男性 5 名, それにボラ ンティア・リーダーの男性 1 名の合計11名であっ た，参加者の一人にジェフさんという人がいた． 製薬会社から出荷された薬を病院に配送する仕事 をしているおじさんで，長いこと独身生活をして いるので趣味が料理ということで，この人のせい で私の体重が増加して帰国することになってしま った.ワーキング・ホリディー中の料理は全部自 主的に当番で作ることになっていて，日本にいる とき何人かのかつての参加者に料理のことを聞く と，イギリスの料理は最低で，毎日ジャガイモを オーブンで料理した物ばかりで，運の悪い人にな ると毎日同じ料理であったそうな。幸か不幸か, 我々のキャンプはジェフさんのおかげで（!?）毎 食豪華イギリス田舎料理とあいなった。この日は, イングランド南部風田舎スープとサラダ, カリフ ラワーのキッシュ、スープの美味しいこと, 美味 しいこと，その日の朝から早く到着して煮込んで くれたとのこと，その上毎食後，甘い甘いデザー トがでるのだ。この日はライスプディングのカス タードがけであった。時差がまだ続いていてなか なか寝付かれなかったが，ヒューヒューという嵐 のような風の音をうつつに聞きながらやっと眠り に入ったらしい.

万歩計 3,740 歩 $(1,500 \mathrm{~m})$ 使ったお金 8 ポンド (1,600円) 